\title{
FEMALE LABOR FORCE PARTICIPATION IN THE MIDDLE EAST AND NORTH AFRICAN COUNTRIES: CONSTRAINTS AND LEVERS
}

\author{
PARTICIPAÇÃO DA FORÇA DE TRABALHO FEMININA NOS PAÍSES DO MÉDIO \\ ORIENTE E DO NORTE DE ÁFRICA: CONSTRANGIMENTOS E POTENCIALIDADES
LA PARTICIPACIÓN DE LA MUJER EN LA FUERZA DE TRABAJO EN LOS PAÍSES DEL ORIENTE MEDIO Y EL NORTE DE ÁFRICA: RESTRICCIONES Y POTENCIALIDADES

\author{
Received: feb/2020 \\ Accepted: feb/2020 \\ Available online: $\operatorname{mar} / 2020$ \\ Chokri kooli, PhD, Telfer School of Management, University of Ottawa, Canada \\ E-mail: ibm4chk@yahoo.fr \\ Hend Al Muftah, PhD, Doha Institute for Graduate Studies, Qatar \\ E-mail: hend.almuftah@dohainstitute.edu.qa
}

\begin{abstract}
Despite the importance of the subject, few researches have attempted to explain the female labor force participation (FLFP) in MENA region. This research tries to exploring the geopolitical, social, ethnic and economic levers or constraints that facilitate or bloc women's access to the labor market. A quantitative approach based on data analysis was performed through the review of the World Bank statistics related to women participation in the labor market in MENA region. Data analysis revealed that the studied labor market was marked by an overall positive progress of the presence of female workers. However, this evolution is still considered very low and slow in comparison with world standards. The research also revealed huge disparities in the level of progress of the FLFP among the studied countries. The disparities observed were interpreted in correlation with the religious, economic, political, social and cultural aspects.
\end{abstract}

BRJPD | Vol. 2 | n. 1 | p. 58-90, 2020. 
Keywords: Female labor force participation, MENA countries, Employment constraints, Employment levers, Women workers.

Resumo: Apesar da importância do tema, poucas pesquisas têm tentado explicar a participação feminina na força de trabalho (FLFP) na região do MENA. Esta pesquisa tenta explorar as potencialidades ou restrições geopolíticas, sociais, étnicas e econômicas que facilitam ou bloqueiam o acesso das mulheres ao mercado de trabalho. Uma abordagem quantitativa baseada na análise de dados foi realizada através da revisão das estatísticas do Banco Mundial relacionadas à participação das mulheres no mercado de trabalho na região do MENA. A análise dos dados revelou que o mercado de trabalho estudado foi marcado por um progresso geral positivo da presença de mulheres trabalhadoras. Contudo, esta evolução ainda é considerada muito baixa e lenta em comparação com os padrões mundiais. A pesquisa também revelou enormes disparidades no nível de progresso da FLFP entre os países estudados. As disparidades observadas foram interpretadas em correlação com os aspectos religiosos, econômicos, políticos, sociais e culturais.

Palavras-chave : Participação da força de trabalho feminina, países do MENA, Restrições de emprego, Potencialidades de emprego, Trabalhadoras.

Resumen: A pesar de la importancia del tema, pocas investigaciones han intentado explicar la participación de la mujer en la fuerza de trabajo (FLFP) en la región MENA. Esta investigación intenta explorar las potencialidades o restricciones geopolíticas, sociales, étnicas y económicas que facilitan o bloquean el acceso de las mujeres al mercado laboral. Se realizó un enfoque cuantitativo basado en el análisis de datos mediante la revisión de las estadísticas del Banco Mundial relacionadas con la participación de la mujer en el mercado laboral en la región MENA. El análisis de los datos reveló que el mercado laboral estudiado se caracterizaba por un progreso positivo general de la presencia de mujeres trabajadoras. Sin embargo, esta evolución se considera todavía muy baja y lenta en comparación con los estándares mundiales. La investigación también reveló enormes disparidades en el nivel de progreso del FLFP entre los países estudiados. Las disparidades observadas se interpretaron en correlación con los aspectos religiosos, económicos, políticos, sociales y culturales.

Palabras clave: Participación de la mujer en la fuerza de trabajo, países de MENA, Limitaciones de empleo, Potencialidades de empleo, Mujeres trabajadoras.

\section{INTRODUCTION}

United Nations and several international organizations guaranteed the general rights

of women and those that are related to labor participation. The provision of women rights came in order to empower and strengthen the status of women in the society and to consider

their own nature. For several decades, females were excluded from the world of work and considered as a mean of reproduction, further creating a one-dimensional depiction of their role as wives and mothers (Kabeer, 2005).

BRJPD | Vol. 2 | n. 1 | p. 58-90, 2020. 
Gradually, the progress of women's rights over time has changed the view of women's status in many Middle Eastern countries and their influential role in society has been recognized. In the MENA region, women remain untapped resources comprising 49 percent of the total population, including more than half of the university students in some countries, and yet make up just 28 percent of the labor force (Yuko, 2015). Recently, the labor market registered an increase of the women's presence in various areas.

The reality of the labor market changed progressively, and new problems emerged at the mixed workplace. For instance, the female physiology and nature is different and necessitates sometimes-special working conditions. However, some studies conducted in the MENA countries revealed that the limited access of women to the labor market is due to the non-protection of their rights through appropriate jurisdictions (Iqbal, 2018). Others considered the cultural and social values and beliefs systems. To better understand women's access to the labor market in the MENA countries, it is necessary to explore the different cultural, social and ethical constraints that may facilitate or limit women access to the labor market.

\section{Gender issues in MENA countries}

Since various factors lie behind FLFP in the MENA, such as social institutions, societal values, female education levels, and employers' preferences in different sectors and industries, it is important to view this issue through multiple lenses. Whitehead, (1979) and Kabir, (2016) observed some gender specific constraints that contributed to expulse women from the job market. These constrains are generally linked to the social relationships and the 
society norms, beliefs and values. These results were supported by Solati (2017) study indicating that women role in the MENA region is greatly affected by female expulsion from the job markets.

Solati (2017) noticed that the social role of women is limited to the performance of house and family duties. Rate of FLFP is literally affected by the strong institutions of patriarchy in the region and by the social role of women Solati (2017). In 2018, the International Labor Organization, estimated that in MENA region reached $20.5 \%$ among female population aged 15 years and plus. For the same period and category, the female labor force participation rate in the World was considerably higher and reached the level of $48.4 \%$.

From her side, Moghadam, (2008) linked the limited presence of female workers, across MENA countries, to the prevalence of discrimination. In fact, women are this discriminated through infrastructure, prevalent laws, regulations, and essentially through the predominance of social barriers. In addition, Rutledge et al. (2011) argue that structural issues and cultural attitudes constitute the main barriers that limit women access to the job market. Robinson, (2005) reported other factors that affects women access to labor market. These factors include social, economic, and demographical parameters such as the level of education, the luck of qualification, the rate of unemployment and the economic stagnation. However, marginal role by the MENA's private sector is another factor.

A report by the World Bank on gender in the MENA region revealed that private sector job creation was too weak to absorb the fast-growing labor force and that mostly young firms and more productive firms that create more jobs. Moreover, various policies across MENA countries limit competition and undermine firm turnover, productivity growth, and job creation (Nabli and Chamlou, 2004).

BRJPD | Vol. 2 | n. 1 | p. 58-90, 2020. 
In her study, Solati, (2015) questioned to why the FLFP rate in MENA region, is the lowest worldwide? Her findings revealed that the patriarchal institution has negatively affected FLFP in MENA. Generally, patriarchy describes male actions of domination and relegates women to play a second role in the society (Tong, 1989, p.3). Based on the radical understanding of feminist theories patriarchy refers to "a sexual system of power in which the male possesses superior power and economic privilege (Eisenstein, 1986).

Several studies (Haghighat-Sordellini, 2010; Hayo and Caris, 2013; Karshenas and al., 2016; Offenhauer and Buchalter 2005) have confirmed that this ideology of patriarchy is highly prevalent in the MENA countries. Several studies explain this negative presence of females in the labor market by the prevalence of some Islamic religious beliefs and ideology, which discourage women from accessing the job market. (H'madoun, 2010; Inglehart et al., 2003; Moghadam, 2008; Psacharopoulos and Tzannatos, 1989; Sharabi, 1988). Other studies (Akailah,2018; Al Suhaim, 2008; Solati, 2015) refuted this argument suggesting that Islam doesn't prevent women from accessing the job market but contrarily invites them to play an important role inside and outside the Muslim society.

Moreover, Solati (2015) completely excluded the religious factor as the reason behind the lower rate of FLFP in MENA countries. She explains the low rates by the high level of wages that are offered in the region and the lack of incentives encouraging women to work. Similarly, Ross (2008) linked the non-participation of women in the job market by their predominant unearned income. In fact, most MENA countries produce oil that offer women and families financial and social benefits that compensate their need for work. The spending of this indirect and unearned income in leisure activities does not leave time for women in order to work Ross (2008). In such regard, Women in MENA region are educated, but do not have the need to work (Solati 2015). 
In the same way, Karshenas \& Moghadam, 2001, explained the lower rates of FLFP by the socio-economic model adopted after the oil boom era. The abundance of natural resources (oil) raised the GDP of the majority of GCC citizens. It generated additional and easy income to families that encouraged women to stay at home, as they are not in need to work. However, with the increased educational attainment of women in the GCCs, their LFFP rate increased gradually as will be explained later. This socio economic conjuncture focusing on strengthening family structures and female socio-economic roles, participated in accentuating the exclusion of women from the job market. In fact, this model was qualified by Karshenas and Moghadam (2001) as incompatible with global economic realities. In other words, studies have shown various factors that may explain the low rate of FLFP in the MENA region. Most studies conducted in this area were mainly based on hypothetical perspectives without making any efforts to collect actual data from each country. In order to understand better inequalities in females' access to the labor market in MENA region, this study will be guided by both, theoretical approach and analytical framework.

\section{2. $\quad$ Research Framework}

\subsection{Methodology}

This research is based on a quantitative approach using data analysis. Through the review of the World Bank statistics related to women access to the labor market in MENA region, we will try to explore the geopolitical, social, ethnic and economic levers or constraints that facilitate or bloc women's access to the labor market. Thus, the research will follow a conceptual model of the behaviour based on pragmatics for abduction (Gabbay and Woods,

BRJPD | Vol. 2 | n. 1 | p. 58-90, 2020. 
2005).

Several researchers like Stigler, 1961 and Simon, 2000, used the cognitive economics in their business research. In fact, behavioral economics approach assume that the critical test of a theory is the exactness of its predictions (Ur Rehman, 2016). Egidi and Rizzello (2003) admitted that cognitive economics helps to understand human mental activities and are relevant to explain economic actions. Ur Rehman (2016) also explained that behavioral economics enhances economics ' explanatory power by providing it with a stronger and more rational psychological foundation. In light of the above, the main hypothesis suppose that the political, social, cultural and religious context of MENA region countries influence considerably on the probability of female access to the labor market. Following an abduction approach, our research will try to understand female choices to access the economic labor market through certain, geopolitical, social, ethics and economic variables. Research objectives consist to: (a) assess the progression of women's rate in the labor force in the studied countries (b) explore the potential impact of the levers and constraints observed in these countries.

\subsection{Data collection and Data Analysis}

This research is essentially based on secondary data through the quantitative analysis of FLFP rate that was defined by the international Labor Organization (ILO) as "the proportion of the population ages 15-64 that is economically active: all people who supply labor for the production of goods and services during a specified period" (ILO, 2019). The countries concerned are situated in the MENA region and include the percentage of female population aged between 15 and 64 .

BRJPD | Vol. 2 | n. 1 | p. 58-90, 2020. 
Data on the labor force was collected and modeled from ILOSTAT database. ILO data is modeled on an estimated basis following international standards. According to the ILO, the series of rates are "part of the ILO estimates and are harmonized to ensure comparability across countries and over time by accounting for differences in data source, scope of coverage, methodology, and other country-specific factors. The estimates are based mainly on nationally representative labor force surveys, with other sources (population censuses and nationally reported estimates) used only when no survey data are available" (ILO, 2019). This research tries to determine the causal relationship between the geopolitical, social, ethnic and economic variables and the access of females to the labor market in MENA countries.

\section{The progress of the FLFP among the studied countries}

According to Leopold, Ratcheva and Zahidi (2016), among the 15 countries with the lowest rates of FLFP 13 countries are situated in the MENA region. The International Labor Organization (ILO) specifies that the labor force participation (LFP) rate refers to the workers that are aged 15 years or older. These persons are economically active and they supply labor for the production of goods and services during a specified period (Bourmpoula and al., 2015, p 11).

Table 1 shows an overall positive progress in term of the access of women to the labor market in the MENA Region. Indeed, between 1990 and 2018, the average rate of FLFP increased from $17.4 \%$ to $20.5 \%$. It means that the FLFP rate for women aged 15 years and plus increased only by $3.1 \%$ in 28 years. This progress shows a positive evolution of the situation of women work in the region. However, compared to the world average $(48.47 \%$ in 2018), the observed rate $(20.5 \%)$ remains very low compared to the world average. In 
addition, if we compare with world regions we conclude that the rate of FLFP in MENA region is very low. For example, in 2018, the FLFP rate in the Sub Saharan Africa was 63\%. In addition, we observed the same ascertainment in the East Asia and Pacific, as the FLFP was $58.8 \%$ in the same year. Again, if we compare the rate observed in the MENA region with the Latin America and Caribbean, we observe a huge gap as the second region registered a rate that reached $51.5 \%$.

Table 1. FLFP participation over time in MENA countries

\begin{tabular}{|c|c|c|c|c|}
\hline \multicolumn{5}{|c|}{ Middle East \& North Africa } \\
\hline \multirow{2}{*}{ Country } & \multicolumn{4}{|c|}{ Year and Variation (1990 to 2018) } \\
\hline & 1990 & 2011 & 2018 & $\%$ variation \\
\hline Algeria & 11 & 15 & 15.3 & 4.3 \\
\hline Bahrain & 29 & 43 & 44.1 & 15.1 \\
\hline Djibouti & 46 & 48 & 49.5 & 3.5 \\
\hline Egypt, Arab Rep. & 21 & 22 & 22.3 & 1.3 \\
\hline Iran, Islamic Rep. & 10 & 15 & 16.5 & 6.5 \\
\hline Iraq & 8 & 18 & 18.9 & 10.9 \\
\hline Jordan & 11 & 15 & 14 & 3 \\
\hline Kuwait & 39 & 49 & 46.8 & 7.8 \\
\hline Lebanon & 19 & 23 & 23.2 & 6.2 \\
\hline Libya & 20 & 26 & 25.7 & 5.7 \\
\hline Malta & 28 & 35 & 42.2 & 14.2 \\
\hline Morocco & 24 & 26 & 24.8 & 0.8 \\
\hline Oman & 20 & 29 & 30 & 10 \\
\hline Qatar & 40 & 53 & 57.8 & 17.8 \\
\hline Saudi Arabia & 14 & 20 & 22.3 & 8.3 \\
\hline Syrian Arab Republic & 22 & 13 & 11.6 & -10.4 \\
\hline Tunisia & 23 & 24 & 24.1 & 1.1 \\
\hline United Arab Emirates & 29 & 43 & 40.6 & 11.6 \\
\hline West Bank and Gaza & 10 & 17 & 19.7 & 9.7 \\
\hline Yemen, Rep. & 17 & 9 & 5.8 & -11.2 \\
\hline
\end{tabular}

Source: International Labour Organization, ILOSTAT database. Early release of the 2017 ILO Labour Force Estimates and Projections, retrieved in September 2018. 


\subsection{FLFP and Economic resources}

If we focus the analysis on the level of progress inside the countries of the MENA region, we observe huge disparities from one country to another. Between 1990 and 2018, three countries situated in the Middle Eastern region were the mostly positively impacted by the increase of the FLFP rate. For this period, we observe that in Qatar, Bahrain and United Arab Emirates the FLFP rate progressed respectively from 40\%, 29\% and $29 \%$ in 1990 to $57.8 \%$, $44.1 \%$ and $40.6 \%$ in 2018 . Thus, in 27 years Qatar improved the FLFP rate by $17.8 \%$. Bahrain and UAE respectively improved their rate by $15.1 \%$ and $11.6 \%$. These positive results place these countries at the hierarchy of the scale of countries that succeeded to highly facilitate the access of women to the labor market in the studied region.

The oil revenue attributed to the acceleration of the educational infrastructure; however, such increased attribution of Qatari females in the labor force is due to the increased access to education, which resulted later in increased opportunities in the labor market. In June 2014, the price of the barrel of Brent crude oil was $111.8 \$$ and continued to tumble down to reach the level of $48.4 \$$ in January 2015 and even less than that for the forthcoming years. The decrease of the oil prices generated a decrease of the FLFP rate in two countries where economy depends on oil and gas revenues.

Perhaps, in Qatar, after progressing for 15 consecutive years, the FLFP slipped for four consecutive years from $42.07 \%$ in 2014 to $57.8 \%$ in 2018 . Indeed, one of the largest changes in Qatar's labor market is in the employment of Qatari women. Qatari FLFP increased from 27.4 percent in 2004 to 34.7 percent in 2013 and to 53 percent in 2014 ( $4^{\text {th }}$ Qatar 4 th national Human development Report, 2015). Generally, Qatari females' participation in the labor force 
increased over the last two decades, where they represent 68 percent of workers in the government sector, 52 percent are occupying professional jobs. This can likely be explained by the higher achievement of females in education, equal pay policy, and acknowledged and recognition in female role models in Qatar, which was enhanced by changing cultural and society's views of Qatari women since the mid-1990s (Al Muftah, 2016).

In UAE, the situation is the same as the FLFP slipped for three consecutive years from $58.9 \%$ in 2015 to $40.6 \%$ in 2018 . In the same context, it seems important to highlight certain disparities between rich countries. In fact, data of the World Bank showed us that in 2017, the GDP of UAE was 382.6 Billion Dollars. For the same period, the Qatari GDP was almost the half of the UAE and generated only 167.6 Billion Dollars. On the other side and despite the huge difference in term of GDP, in 2017, the UAE rate of FLFP was $41 \%$ and the Qatari Ones was 58\%. Therefore, we can say, that in Qatari women benefited better from the petrol boom.

On the other far side, the kingdom of Saudi Arabia constitutes an exception among the countries that revenues relay on the oil revenues. In fact, no correlation is observed between the increase of oil prices and the FLFP. Over years, this rate slightly moved from $14.1 \%$ in 1990 to $22.3 \%$ in 2018 . So in the space of 28 years, the FLFP rate increased by only $8.2 \%$ and stands far away from countries that relay on oil revenues. Indeed, for the same period Qatar, Bahrain and UAE improved their FLFP, respectively by $18 \%, 15 \%$ and $12 \%$. Again, in 2017 , the GDP of Saudi Arabia reached the level of 683.8 Billion Dollars and stands in the first rank among the previously cited countries. Despite that, the FLFP rate was the weakest among the cited countries and reached the level of $22.25 \%$ in the same year. This might be attributed to the very conservative society during that period compared to the other three GCCs: Qatar, UAE and Bahrain.

BRJPD | Vol. 2 | n. 1 | p. 58-90, 2020. 
In addition, during the last period of gas and oil crises, despite the decrease of revenues generated, the Saudi rate of FLFP was not affected and raised from $20.7 \%$ in 2014 to $22.3 \%$ in 2018. Therefore, in the case of Saudi Arabia, we concluded that unlike the other GCCs, that the rate of FLFP is not correlated to the oil revenues and women did not benefit from the naturel resources of the country. Therefore, it can be argued that other social and cultural factors affected the rate of FLFP in the GCCs. In this regard, it seems important to highlight the case of Djibouti. In 2017, The GDP of the country generated, only 1.845 billion dollars. However, at the same time, with limited financial resources, Djibouti stands in the second rank of the best countries in the region in term of FLFP. In fact, almost half (49.5\%) of the Djibouti women are active on the job market. Here we can conclude that the poverty of the country pushed women to relay on themselves rather than relying on men. That is why they massively invaded the labor market. Generating a second income to the family could improve their wellbeing.

\subsection{FLFP and the security context}

Despite the promising progress observed in certain countries, the rate of FLFP was almost stable and even some times negative in certain countries. For example, the data analysis shows as that, between 1990 and 2018, this rate regressed respectively by $10.4 \%$ and 11.2\% in Syria and Yemen. This shows that the situation of women deteriorated due to the civil war in both countries.

In Yemen, the Best rate of FLFP was registered in 1999 with $21.7 \%$. The political instability and the ethnic denominations created a frustration among the population and generated in 2004 the beginning of the war of Sa'dah. In that year, the FLFP rate was $15.4 \%$ and started to regress progressively to reach the rate of 8.8 in 2011. The year after, the Yemen

BRJPD | Vol. 2 | n. 1 | p. 58-90, 2020. 
popular revolution and civil war busted and generated a serious deterioration of the humanitarian, sanitarian and health conditions of Yemenite citizens.

The civil war of Yemen affected a larger proportion of women in the labor force than men. In 2015, male employment had declined by 11 percent, while female employment had fallen by 28 percent. These figures varied nationally; 43 percent of the employment decline for women occurred in Sana'a, due to the heavily hit private sector, while in Aden the number of women in employment actually rose by 11 percent (Sana's Centre for Strategic Studies, 2019). In 2017, the world health organization issued a report in which they determined that 18.8 Millions of Yemenite are in need of Humanitarian aid. It also concluded that 2.1 Million are still unable to return to their homes (WHO, 2017). Another report issued in 2018, by the Human Rights Council admitted that since September 2014, the economic and social wellbeing of women and children deteriorated (HRC, 2018, p.12).

Despite the differences observed in the political conjuncture, the outcomes of the war are the same in Yemen and Syria. Thus, on March 15, 2011, a major unrest began in Syria. A consensus was not observed in term of the qualification of the Syrian war. For some people it is a civil war, for other it is the revolution of dignity (Omri, 2012). Despite that fact, the Syrian war generated, almost the same damages to the female workers. By the end of 2010 and just before the beginning of the war, the Syrian FLFP rate was $13.2 \%$. This rate regressed to $11.8 \%$ in 2017 and reached $11.6 \%$ in 2018.

According to the Syrian Observatory for Human Rights, by 2018, More than 560000 were reported as killed or missing (SOH, 2018). In 2018, the security council of the United Nations notified in Syria a dangerous widespread of violations and abuses of human rights and violations of international humanitarian law. Thus it expressed a "grave concern at the more 
than 5.6 million refugees, including more than 4.2 million women and children, who have fled Syria as a result of ongoing violence" (Singh and Strol., 2019).

Unfortunately, the humanitarian situation will continue to deteriorate and consequently the situation of female workers will continue to degenerate. Therefore, it is clear that the political instability of these two countries directly influenced the overall socioeconomic status and further lowering the rate of FLFP. In the same context of war, the situation of women is completely different in Palestine as the rate of FLFP moved positively from $10.2 \%$ in 1990 to $19.7 \%$ in 2018 . In Palestine, the situation of women is affected by the Israeli occupation and the Intifada, where women took over the economy due to the increase number of men prisoners, wounded or killed.

According to the Israeli Journal Haaretz, since 1967 imprisoned Israel over 800,000 Palestinians. The Palestinian negotiator Saeb Erekat affirmed that "For Palestinians, having loved ones in prison is not the exception - it is something which has affected every Palestinian family. The numbers reflect one of the worst experiences of imprisonment in contemporary history, designed to break the will of an entire nation seeking freedom" (Haaretz, 2014). The Palestinian uprising against the Israeli occupation of the West Bank and Gaza was called the first Intifada. It started in December 1987 and in theory finished in 1991. Nevertheless, Palestinians continued to defend their territories and the Israeli Occupation continued to kill and jail Palestinians and especially male ones.

Another country of the MENA region was also in a similar security situation. In 2003, Iraq was invaded by a coalition led by the United States. The government of Saddam Hussein was overthrown and the American Forces continued to be present there and combat until 2011. Despite the war context, the FLFP rate positively progressed from $12.6 \%$ in 2003 to $18.1 \%$ in 2011. After the end of the war, the FLFP continued to increase and reached the level 
of $18.9 \%$ in 2018. By Paradox, this means that during war the FLFP increased by an average of $0.68 \%$ per year and during the 7 years following the war, it progressed by only $0.86 \%$ and a yearly average of $0.12 \%$.

We conclude that security, instability and war, in general, negatively and directly affect the working conditions of women and generally lead to a decrease of the presence of women in the market place. However, data analysis revealed that the negative correlation between this variable and the FLFP is not always evident. This variable could not be fully and exclusively linked to the variation of this indicator as we observed that the deterioration of the political context and the situation of war could generate in certain cases positive incomes on the FLFP rate. Thus, in this context, women play an important role in the economic supply of men role.

\subsection{FLFP and Political stability}

Some countries of the MENA region including Egypt, Tunisia, and Libya, have known radical political changes due to the Arabic Spring movements. In 1981, Muhammad Hosni Mubarak, former military leader served as the fourth President of Egypt. The Egyptian revolution against the president Hosni Mubarak and his political system started on January 25, 2011.

Contrarily to the Syrian and Yemenite revolutions, the Egyptian one was pacifist, nonviolent (Shahin, 2012) and essentially consisted of demonstrations, civil disobedience and strikes. Through all these means of protestations, the Egyptian citizens raised their voice and claimed "the change of the regime". In fact, Egyptians said they were tired of the political regime that limits civil liberty, freedom of speech and political freedom. Citizens also protested against the low wages, high unemployment rates, discriminations and corruption. The 11th of February 
2011, Hosni Mubarak resigned from his position as president and the Supreme Council of Egyptian Armed Forces took the leadership of the country.

Using unique information from the Statistical Database of the Egyptian Revolution, ElMallaeh, et al, 2017, find that the 2011 protests have reduced the gender gap in labor force participation by increasing women's unemployment and private sector employment. The political change has mostly affected the relative labor market outcomes of women in households at the bottom of the pre-revolution income distribution.

One year later, The Egyptian citizens democratically elected representatives of the People's Assembly and the new Egyptian president Mohammed Morsi. The 3rd of July 2013, the Supreme Council of Egyptian Armed Forces overthrew the first democratically elected president of Egypt. A new presidential election was organized and Al Sissi became the new President of Egypt on June 8, 2014. The following of the evolution of the FLFP rate shows a certain stability in Egypt. In fact, in 1990 and during the Mubarak's regime, the FLFP was $21.3 \%$ and remained almost stable until 2010 , the year before the resignation of the president (22.7\%). This stability observed in the rate of FLFP remained even during the subsequent years of political instability and reached the level of $22.3 \%$ in 2018.

The $7^{\text {th }}$ of November 1987, the former military leader Zine el Abidine Ben Ali became the second president of Tunisia after a bloodless coup d'état. His political regime was marked by dictatorship, autocracy, corruption, social and economic crises. Tunisian citizens were oppressed, lacking political and speech freedom, mostly unemployed and living in poor conditions. The end of the year 2010 was marked by a spontaneous revolution combined with an intensive campaign of civil resistance and street demonstrations. The pacific efforts of citizens contributed to the ejection of Ben Ali from the throne in January 2011.

BRJPD | Vol. 2 | n. 1 | p. 58-90, 2020. 
Since that, a new constitution was adopted and the country lived for the first time two free and democratic legislative and presidential elections. In 1990, 3 years after Ben Ali bloodless coup d'état, the Tunisian FLFP rate reached the level of $22.5 \%$. This indicator remained stable ( $24.4 \%$ by end 2010 ) till the end of the political regime of Ben Ali. Despite the political instability observed in Tunisia between 2011 and 2018, the main indicator of our research has been stable at the level of $24 \%$. In fact, in 2018, the Tunisia female labor force participation rate was $24.1 \%$. Thus, we understand that the situation of women workers was the same during the whole period of Ben Ali's governance and during the post dictatorship regime. The political stability or instability did affect the Tunisian female workers.

The North African side of the MENA region was marked by a third revolution initiated by the Libyan citizens. Like in Tunisia and Egypt, Libya was governed by a very long episode of military dictatorship. The first of September 1969, the colonel Gaddafi become the revolutionary Chairman and leader of the Libyan Arab Republic. Following the start of the Arab Spring in 2011, major protests broke out against Gaddafi's government. In that time, Libyan protestors were extremely outrageous against the incapacity of the government in resolving the unemployment issues, the widespread of corruption and entrenched systems of patronage (Kawczynski, 2011; St John, 2017). On October 20, the decease of Colonel Gaddafi marked the end of the Libyan revolution and opened the door of the era of post-revolution armed groups and violence. The new republic of Libya remains in a worrisome period of political instability and tribal disputes.

In contrary to Egypt and Tunisia, the Libyan regime was able to register better results in term of the presence of women in the labor market. In fact, between 1990 and 2011, the Libyan rate of FLFP raised by 6.2 points and reached the level of $26.2 \%$. For the same period, Tunisian government improved his indicator by 1.6 points and the Egyptian ones by 0.6 points. 
Despite its importance, thus success remains without importance and value when we compare Libya with other countries that generate huge revenues from the oil and gas resources. When we focus the analysis on the period of political instability, we notify that between 2011 and 2018 , the FLFP was almost stable, regressed by only $0.5 \%$ and reached the level of $25.7 \%$. Thus, we understand that the revolution and political instability of Libya did not generate a considerable improving or deterioration of the possibilities of presence of women in the labor market.

In general, we can say that the FLFP rate in the three countries that were affected by revolutions and political instability are almost the same. Over a period of 7 years, the FLFP rate in Egypt, Tunisia and Libya was situated between $22 \%$ and $25 \%$ with no increase or decrease. Thus, we conclude that the political context conjugated by social revolutions did not contribute to the improvement of the rate of access of Women to the labor market. No positive or negative correlation was observed for the short and mid-term. Revolutions and political instability did not contribute to considerable ameliorations of the situation of the female workers and their presence in the labor market. From another side, we can also conclude that revolutions did not also generate a deterioration of the working conditions of women. This ascertainment needs to be observed on a longer period in order to get much more accurate data and consolidate findings.

\subsection{Qatar's leadership}

On a large scale of Analysis, data showed in table 1 reveals huge disparities between countries of the same region. For example, Qatar registered the highest FLFP rate with an increase of 18 points and reached the level of $57 \%$ in 2018 . For the same period and region, 
in Algeria, the FLFP progressed only by $4 \%$ and moved from $11 \%$ in 1990 to $15.3 \%$ in 2018 . Here we compare between countries that generate important revenues from the resource of natural gas. As example, according to the World Bank, in 2017, the Gross domestic product in Algeria was 170.4 billion USD. For the same period, the GDP in Qatar reached the level of 167.6 billion USD. Thus, we conclude that the revenues generated by the Algerian government were not spread equally among the population and consequently marginalized the investment in creating jobs for women. Contrarily, the Qatari government believed in the importance of sharing the richness among the population and believed in the importance of creating new jobs for women.

The data collected through ILOSTAT database of the International Labor Organization, shows us the increasing leadership of Qatar in term of FLFP. Indeed, by cumulating 18 points of positive progress between 1990 and 2018, Qatar registered the highest increase of the FLFP in the region for the same period. In addition, in 2018, Qatar leaded the countries of the studied region by reaching the level of $57.8 \%$ of FLFP. Djibouti and Kuwait ranked second and third by registering respective rates of $49.5 \%$ and $46.8 \%$. The excellent results registered in Qatar and Djibouti; place them as the only two countries in the region that reached a FLFP rate that is above the world average.

Indeed, the ILOSTAT database indicated that in 2018, the female labor force participation average rate reached the stage of $48.4 \%$. In addition, the excellent result registered in Qatar place it in a better position comparing to countries that are leaders in term of women rights protection. Indeed, in 2018 , Qatar's FLFP was $57.8 \%$, the same year; countries like UK, USA and France registered a lower FLFP with respectively 56.8\%, 55.4\% and 50.4\%. Many factors were behind such increased remarkable FLFP of Qatari women, most importantly supportive political leadership, new role model of Qatari women represent in her 
highness Shikha Moza bin Nasser, expanded and diverse access to education, and expanded and diverse access to labor market including previously male-dominated jobs and sectors as engineering and military and private sector.

\subsection{FLFP and Islamic religion}

The data analysis shows us some regional disparities. In 2017, the best FLFP in North Africa was registered in Libya (26\%). The rate of the rest of the North African countries is quietly close from what was seen in Libya. Contrarily, the richest countries of the Middle East that depend essentially on petrol incomes registered important rates of FLFP. Between Qatar, UAE, Kuwait, and Bahrain, the lowest FLFP rate was registered in UAE and was $41 \%$. This last conclusion does not apply for Saudi Arabia and Oman where we notified respectively $22 \%$ and $30 \%$ of FLFP rate.

In 2010, Islam represents the world's second-largest religion in the world with an estimated 1.6 billion Muslims around the world (Hackett et al., 2012). Almost, 317 million Muslims live in the Middle East-North Africa region, which represents $20 \%$ of the Muslim population (Hackett et al., 2012). In 2013, Lugo et Al. (2013) have conducted a research in order to explore the attitudes of Muslims toward Islamic law (Sharia). Researchers conducted more than 38,000 face-to-face interviews with Muslims residing in 39 countries. The researchers concluded that the attitudes toward Islamic law vary significantly by region. They also notified that $74 \%$ of Muslims living in the Middle East-North Africa region support the idea of making sharia the law of the land. They also concluded that the support of the Sharia law among Muslims is higher in the Middle Eastern side compared to the North African side.

BRJPD | Vol. 2 | n. 1 | p. 58-90, 2020. 
In 2018, Pew Research Centre released a report that aims to understand religious change, including the demographic patterns shaping religion around the world. The report was based on the analysis of surveys collected over the last decade in 106 countries through 13 different Pew Research center studies. Essentially, the research focused on four standard measures of religious commitment, including affiliation, importance of religion, worship attendance and frequency of prayer (Hackett, Stonawski \& McClendon, 2017; Hackett and al., 2018). The research concluded that religion is more central to everyday life for Muslims in North Africa and the Middle East. For them, religion is 'very important'. Nevertheless, the data analyzed through the report show certain disparities between countries and regions. In fact, the four standards of measure of religious commitment show a higher commitment in the Middle East region in comparison to the North African one.

The literature review showed us that several studies (H'madoun, 2010; Inglehart et al., 2003; Moghadam, 2008; Psacharopoulos and Tzannatos, 1989; Sharabi, 1988) explain the low rate of FLFP in MENA by the Islamic religious beliefs and ideology, which discourage women from accessing the job market. These researchers argued that the dominant religion in the MENA region negatively affected the rate of female labor force participation. Research conducted by Lugo and Al., 2013; Hackett, Stonawski \& McClendon., 2017; Hackett and al., 2018) clearly indicated that the religious beliefs are strong and dominant in the Middle East region. Contrarily, the countries of North African side are considered as more open and less attached to Islam principles.

Through our research, the statistics collected from the World Bank regarding the FLFP participation show us that the majority of the Middle East countries registered FLFP rates that are higher than what was observed in the North African countries. The rates of the Middle East countries are at least equivalent (Saudi Arabia, Iraq, Lebanon) or much higher (Qatar, BRJPD | Vol. 2 | n. 1 | p. 58-90, 2020. 
Kuwait, UAE, Bahrain) from the North African rates. Despite the fact that we cannot establish a direct link between Islamic religion and the FLFP rates, the statistics collected from the World Bank clearly showed us that the FLFP rates are higher in the Middle East countries where the attachment to the religion is highly prevalent. Contrarily, in the North African countries, where the degree of attachment to the Islamic values is less dominant, the rates of FLFP are considerably lower. Thus, data shows that the rate of female labor force participation is higher in countries that are strictly attached to the Islamic principles than those that are not. Consequently, it appears that Islamic religion is not a constraint for the female work. The data revealed that Islamic religion is a lever for female participation in the labor market.

\section{Discussion}

The aims of this study is to explore the geopolitical, social, ethnic and economic levers or constraints that facilitate or bloc women's access to the labor market. The research revealed two dominant themes: the progression of women's rate in the labor force in MENA region (b) the potential impact of the levers and constraints observed in these countries.

Findings show us an overall positive progress in term of the access of females to the labor market in the MENA Region. Indeed, between 1990 and 2018, the average rate of FLFP increased by only $3 \%$ while the international average decreased by $2.5 \%$ for the same period according to the world bank. This progress shows a positive evolution of the situation of female workers in the region. However, this rate is still considered very low compared to the world average that was the double of the rate observed in the MENA region in 2018. In addition, the research revealed that the level of progress of the FLFP inside the studied 
countries registers huge disparities from one country to another.

The second part of the research showed us that factors like the Economic, social, religious, political and security context of certain countries positively and or negatively affected the conditions of access of women to the labor market. Contrarily to the common ideas, the data analysis showed us that the Islamic religious variable positively influenced the rate of female labor force participation. The theoretical approach and analytical framework adopted by kabeer (2015) in order to explain gender inequalities in the labor market outcomes relays essentially on individual choice (Polachek, 1981; Becker, 1971; Arrow, 1973). Our research revealed that individual choices played a secondary role in explaining gender inequalities in MENA countries. Legal, political, social and security conjunctures greatly influenced positively and negatively on the access rate of females to the labor market.

Additional findings provide highly promising findings and more insights explaining the fluctuations and disparities in term of the progress of FLFP in MENA countries. Through this research, we were able to observe a positive evolution of the situation of the female workers in the region conjugated by the increase of the FLFP rate. This evolution is consistent, but is still considered as very slow. It is also important to notify the disparities of the evolution between the different studied countries. A huge gap is observed as some countries registered fast evolutions and reached rates that are comparable to the world average. Contrarily, the evolution of the FLFP is very slow in other countries and sometimes is negative. Essentially, we can say that the richest countries of the Middle East that depend essentially on oil revenues registered important progress of the rates of FLFP. Typically, this fact can be explained by the openings observed in the public sector of these rich countries. The abundance of financial resources gives the opportunity to these countries to create new 
opportunities of employment. Therefore, as women are better educated and more skilled than men in these countries, they got the opportunity to work in the public sector. It is also necessary to mention that this sector of employment offer better advantages and conditions of work. Thus, women are attracted and motivated to work with their government. This explains why the rates of FLFP increased considerably in the Middle East countries.

In addition, data revealed that rate of FLFP decreased in countries that are in war. Therefore, we conclude that the security context and instability affect directly on women work rates and consequently drive to the regression of the rates of the women access to the labor market. With the same line of ideas, we concluded that the political context conjugated by social revolutions, which happened recently in certain countries of the region, did not contribute to the improvement of the rates of access of Women to the labor market. We were not able to observe a positive correlation between the Arab spring revolutions and the rates of FLFP. These revolutions did not result in the creation of new opportunities of employment for women. At the same time, they did not affect them negatively. The situation is stable before and after the Arabic spring. No positive correlation was observed for the short and midterm. These facts needs to be observed on a longer period in order to get much more accurate findings.

Another valuable finding shows that the rate of female labor force participation is higher in countries that are strictly attached to the Islamic principles than those that are not. The Middle East region, where Islamic rules are strictly followed, contains the highest rates of FLFP. Contrarily, in the North African side that is known as more open and less attached to the Islamic principles, the rates of FLFP are low and too far from what is observed at the international level. Therefore, we conclude that, as religion, Islam encourages women to work and participate in the economic development and maintain the prosperity of the society. This 
conclusion shows that the common idea stipulating that Islam embed women from accessing to the labor market could not be supported. It is evident that religion does not constitute a constraint for women work and the low rates of FLFP registered in certain countries need to be linked to other variables.

This study focuses on the impact of the Economic, political, social and religious context on the possibilities of access of women to the labor market. As far as we know, there are only few researches that concretely studied the constraints and levers on the FLFP rates in the MENA region. The majority of previous researches are descriptive rather than being analytical. We tried to explore the different constraints facing female workers in the MENA region. Unfortunately, we were not able to see a concrete evolution in term of FLFP rates.

Several disparities between the countries observed are still existing and easily detectable. In summary, we suggest that MENA region countries make the Benchmarking efforts and gain profit from the best legal dispositions and regulations observed in similar social, cultural and religious context. By doing so, we facilitate access of women to the labor market and optimize chances of economic development.

Certain MENA countries need also to rationalize the use of natural resources and allocate a reasonable part of the GDP generated in order to create new opportunities of employments to the female workers. The public policies followed by certain Middle East countries generated highly desirable outcomes and facilitated the female access to the labor market. The other countries of the region need to follow the model of Qatar, UAE, Kuwait and Bahrain. The MENA countries policy makers need also to work hard on changing certain social and cultural barriers that could limit the access of females to the labor market. This research clearly concluded that the Islamic religion is not a barrier that limits women chances of BRJPD | Vol. 2 | n. 1 | p. 58-90, 2020. 
employment. Thus, the Arabic perception conjugated by social and cultural factors, which see the female work as socially unacceptable, need to change. In addition, the MENA region is known by the geopolitical conflicts.

The research showed that the social revolutions did not affect the conditions of access of women to the labor mark. Contrarily, wars severely affected women on different aspects. The studied cases showed that the decrease of the FLFP is negatively correlated with the deterioration of the security conditions of certain countries. The security of the nation is another factor that could encourage females to access the labor markets. A high level of political and social stability are considered as essential factors that could consequently improve the FLFP rates.

\section{Conclusion}

The efforts deployed by certain countries of the MENA region in order to encourage women access to the labor market are considerable and highly appreciated. Contrarily, other countries from the same region are still too far from reaching reasonable levels of FLFP. Economic, Social, political and cultural barriers could explain the disparities of rates observed in the studied countries. Some good practices are followed and more efforts are still necessary in order to improve rates of FLFP. Studying the women employment in a regional context is a risky step and findings are always compromising.

The levers and constraints that face women's in employment are different and depends more on the Social, political, economic and religious context of the country or the region. Generalizing findings specific to one country among other countries is a dangerous 
step that can affect the scientific integrity of the research. The findings reveal new insights on the reality of the women work in the MENA region under the Economic, social, political and cultural context.

\section{REFERENCES}

Akailah, Z. (2018), Rights of working women: comparative study between Islamic sharia and status law, revue mofakir (08).

Al Muftah, Hend, (2016), Demographic Policies and Human Capital Challenges, in M. Evren Tok, Lolwah R.M. Alkhater and Leslie A. Pal, (2016) Public Policy in a transformative State: The case of Qatar, (2016), Palgrave, Macmillan publisher limited, PP 271-294

Arrow, K. (1973). The theory of discrimination. Discrimination in labor markets, 3(10), 3-33.

Becker, G. (1971). The Economics of Discrimination. Chicago: Univ

Bourmpoula, V., Kapsos, S., \& Pasteels, J. M. (2015). ILO labour force estimates and projections: 1990-2050, Methological description (2015 edition). ILO Geneva.

Eisenstein, Z. R. (1986). The radical future of liberal feminism. Boston: Northeastern University Press.

El-Mallaeh, Nelly, Mathilde marunel, and Biagio Speciale, (2017), Arab spring Protests and women's labour: evidence from Egyptian revolution, working paper 957, The Economic Research Forum.

Gabbay, D and Woods, J. (2005). The Structure of Abduction, in A Practical Logic of Cognitive Systems, Elsevier, Volume 2, Pages 39-73,

BRJPD | Vol. 2 | n. 1 | p. 58-90, 2020. 
Haaretz News Paper (2014). Over 800,000 Palestinians Imprisoned by Israel since 1967.

Published Apr 17, 2014. https://www.haaretz.com/.premium-800-000-palestinians-jailedsince-67-1.5245393

Hackett, C., Grim, B., Stonawski, M., Skirbekk, V., Potančoková, M., \& Abel, G. (2012). The global religious landscape. Washington, DC: Pew Research Center.

Hackett, C., Stonawski, M., \& McClendon, D. (2017). The changing global religious landscape. Pew Research Center.

Hackett, Conrad \& Kramer, Stephanie \& Marshall, Joey \& Shi, Anne \& Fahmy, Dalia. (2018). The Age Gap in Religion Around the World. Pew Research Center

Haghighat-Sordellini, E. (2010). Women in the Middle East and North Africa: change and continuity. Springer.

Hayo, B., \& Caris, T. (2013). Female labour force participation in the MENA region: The role of identity. Review of Middle East Economics and Finance, 9(3), 271-292.

H'madoun, M. (2010). Religion and labor force participation of women.

https://data.worldbank.org/indicator/SL.TLF.ACTI.FE.ZS?locations=ZQ

Human Rights Council (2018). Situation of human rights in Yemen, including violations and abuses since September 2014. https://undocs.org/A/HRC/39/43

ILO, (2015), "Yemen Damage and Needs Assessment - Crisis Impact on Employment and Labour Market" ILO, January 2016, https://www.ilo.org/wcmsp5/groups/public/arabstates/-ro beirut/documents/publication/wcms 501929.pdf. Accessed March 19, 2019.

Inglehart, R., Norris, P., \& Ronald, I. (2003). Rising tide: Gender equality and cultural change around the world. Cambridge University Press.

BRJPD | Vol. 2 | n. 1 | p. 58-90, 2020. 
International Labour Organization (2019). ILOSTAT database. Labor force participation rate, female (\% of female population ages 15-64) (modeled ILO estimate) - Middle East \& North Africa, Data retrieved in September 2019.

Iqbal, S. ( 2018). Women, Business, and the Law 2018 (English). Washington, D.C. :

World Bank Group.

http://documents.worldbank.org/curated/en/926401524803880673/Women-Business-andthe-Law-2018

Kabeer, N. (2005). Gender equality and women's empowerment: A critical analysis of the third millennium development goal 1. Gender \& Development, 13(1), 13-24.

Kabeer, N. (2015). Gender, poverty, and inequality: a brief history of feminist contributions in the field of international development. Gender \& Development, 23(2), 189205.

Kabir, N. (2016). Women's economic empowerment and inclusive growth: labour markets and enterprise development. School of Oriental and African Studies, UK.

Karshenas, M., \& Moghadam, V. M. (2001). Female labor force participation and economic adjustment in the MENA region. In The economics of women and work in the Middle East and North Africa (pp. 51-74). Emerald Group Publishing Limited.

Karshenas, M., Moghadam, V. M., \& Chamlou, N. (2016). Women, work, and welfare in the Middle East and North Africa: introduction and overview. In Women, work and welfare in the Middle East and North Africa: The role of socio-demographics, entrepreneurship and public policies (pp. 1-30).

Kawczynski, D. (2011). Seeking Gaddafi: Libya, the West and the Arab Spring. Biteback Publishing.

BRJPD | Vol. 2 | n. 1 | p. 58-90, 2020. 
Leopold, T. A., Ratcheva, V., \& Zahidi, S. (2016). The global gender gap report 2016. In World Economic Forum.

Lugo, L., Cooperman, A., Bell, J., O'Connell, E., \& Stencel, S. (2013). The world's Muslims: Religion, politics and society. World.

Massimo, E., \& Salvatore, R. (2003). Cognitive economics: Foundations and historical evolution (No. 200304). University of Turin.

Ministry of Planning Development and Statistics, (2015), $4^{\text {th }}$ National Human Development Report, 2015.

Moghadam, V. M. (2008). Feminism, legal reform and women's empowerment in the Middle East and North Africa. International Social Science Journal, 59(191), 9-16.

Mohammed Al suhaim (2008), Islam: its origins and principles.

Morikawa, Y., \& Brookings Institution (Washington, DC). (2015). The opportunities and challenges for female labor force participation in Morocco. Brookings Institution.

Nabli, M. K., \& Chamlou, N. (2004). Gender and development in the Middle East and North Africa: Women in the public sphere. World Bank.

Offenhauer, P., \& Buchalter, A. R. (2005, November). Women in Islamic societies: a selected review of social scientific literature. Washington, DC: Federal Research Division, Library of Congress.

Omri, M. S. (2012). A Revolution of Dignity and Poetry. boundary 2, 39(1), 137-165.

Pew Research Center, June 13, 2018, "The Age Gap in Religion Around the World. http://www.pewforum.org/wp-content/uploads/sites/7/2018/06/ReligiousCommitmentFULL-WEB.pdf 
Polachek, S. W. (1981). Occupational self-selection: A human capital approach to sex differences in occupational structure. The review of Economics and Statistics, 60-69.

Psacharopoulos, G., \& Tzannatos, Z. (1989). Female labor force participation: An international perspective. The World Bank Research Observer, 4(2), 187-201.

Robinson, J. (2005). Female labor force participation in the Middle East and North Africa. Wharton research scholars journal, 28.

Ross, M. L. (2008). Oil, Islam, and women. American political science review, 102(1), 107-123.

Rutledge, E., Al Shamsi, F., Bassioni, Y., \& Al Sheikh, H. (2011). Women, labour market nationalization policies and human resource development in the Arab Gulf states. Human Resource Development International, 14(2), 183-198.

Sana's Centre for Strategic Studies, (2019), The repercussions of war on women in the Yemeni workforce. Accessed on 3rd Feb 2020. https://sanaacenter.org/publications/mainpublications/7721\#_ftn27

Shahin, E. E. D. (2012). The Egyptian revolution: The power of mass mobilization and the spirit of Tahrir Square. The Journal of the Middle East and Africa, 3(1), 46-69.

Sharabi, H. (1988). Neopatriarchy: A theory of distorted change in Arab society. Oxford University Press, USA.

Simon, H. A. (2000). Bounded rationality in social science: Today and tomorrow. Mind \& Society, 1(1), 25-39.

Singh, M and Strol, D. (2019). Syria study group: Final report and recommendations. United States Institute of Peace. https://www.usip.org/sites/default/files/Syria\%20Study\%20Group\%20Final\%20Report.pdf Solati, F. (2015). Female labor force participation in the Middle East and North Africa. 
Solati, F. (2017). Women, Work, and Patriarchy in the Middle East and North Africa. Springer.

St John, R. B. (2017). Libya's gender wars: the revolution within the revolution. The Journal of North African Studies, 22(5), 888-906.

Stigler, G. J. (1950). The development of utility theory. I. Journal of political economy, 58(4), 307-327.

Syrian Observatory for Human Rights (2018). In about 93 months... about 560 thousand were killed in Syria since the day of claiming rights to the international human rights day. http://www.syriahr.com/en/?p=108723

Tong, R. (1989). Feminist thought: A comprehensive introduction. Boulder: Westview Press.

United nations (2018). Security Council, Adopting Resolution 2449 (2018), Authorizes One-Year Extension of Cross-Border Aid Deliveries Targeting 13 Million in Syria. https://www.un.org/press/en/2018/sc13620.doc.htm

ur Rehman, T. (2016). Historical context of behavioral economics. Intellectual Economics, 10(2), 128-132.

Whitehead, A. (1979). Some Preliminary Notes on the Subordination of Women 1. The IDS Bulletin, 10(3), 10-13.

World health organization (2017). Health situation in Yemen and WHO response since March 2015. https://www.who.int/hac/crises/yem/yemen-infographic2.pdf?ua=1 